Tourist Engagement and Loyalty: Gender Matters?

\author{
S. Mostafa Rasoolimanesh \\ School of Hospitality, Tourism and Events \\ Taylor's University; Subang Jaya; Malaysia \\ rasooli1352@yahoo.com \\ mostafa.rasoolimanesh@taylors.edu.my \\ Catheryn Khoo-Lattimore \\ Griffith University, Australia \\ c.khoo-lattimore@griffith.edu.au \\ Shuhaida Md Noor \\ School of Communication \\ Universiti Sains Malaysia, 11800, Penang \\ shuhaida@usm.my \\ Mastura Jaafar \\ School of Housing, Building, and Planning \\ Universiti Sains Malaysia, 11800, Penang \\ masturaj@usm.my \\ Rupam Konar \\ School of Hospitality, Tourism and Events \\ Taylor's University; Subang Jaya; Malaysia \\ Rupam.Konar@taylors.edu.my
}




\title{
Tourist Engagement and Loyalty: Gender Matters?
}

\begin{abstract}
This study aims to compare the effects of several dimensions of tourist engagement, including enthusiasm, attention, absorption, interaction, and identification on loyalty across male and female tourists. A total number of 210 questionnaire were completed from tourists visiting Kinabalu National Park in Sabah, Malaysia. This study uses both partial least squares structural equation modeling and fuzzy-set qualitative comparative analysis to elucidate further insights. The results showed significant differences between the effects of attention on loyalty, with this effect being much stronger for male tourists. However, the findings demonstrated more complex sufficient configurations and heterogeneity among female tourists for achieving high levels of loyalty. This study makes a significant contribution to the research literature by comparing the engagement and loyalty of male and female tourists toward a destination, having identified greater heterogeneity among female tourists. This study has a number of practical implications for local authorities aiming to improve loyalty among male and female tourists.
\end{abstract}

Keywords: Tourist engagement, loyalty, gender, partial least squares - structural equation modeling (PLS-SEM), fuzzy-set qualitative comparative analysis (fsQCA), necessary condition analysis (NCA) 


\section{Introduction}

Several studies have investigated the concept of tourist engagement with a destination and its subsequent effects on tourist loyalty and intentions to revisit (Brodie, Hollebeek, Jurić, \& Ilić, 2011; Rasoolimanesh, Md Noor, Schuberth, \& Jaafar, 2019; Vivek, Beatty, \& Morgan, 2012). Previous studies have confirmed the importance of tourist engagement on the development of a tourism destination (Bowden, 2009; Bryce, Curran, O’Gorman, \& Taheri, 2015; Leckie, Nyadzayo, \& Johnson, 2016). Improving tourist engagement increases tourist satisfaction, loyalty, and intentions to revisit a destination (Bowden, 2009; Bryce et al., 2015). Nevertheless, the tourist engagement research is dominated by relationship marketing and organizational behavior theories (So, King, \& Sparks, 2014). From the relationship marketing perspective, tourist engagement refers to the net tourist experience of interacting with other stakeholders and the environment; whereas from the organizational behavior perspective, tourist engagement is concerned with cognitive and emotional domains (Brodie, Ilic, Juric, \& Hollebeek, 2013). Both behavioral and psychological aspects of tourist engagement have significant effects on loyalty and the intention of tourists to revisit a destination; nevertheless, some differential effects between male and female tourists are to be expected in light of variations in the psychological and behavioral characteristics of each gender (Kim, Chiang, \& Tang, 2017). Few studies, however, have investigated the influence of gender on tourist engagement or loyalty, or the heterogeneity of effect of tourist engagement on loyalty across gender. Therefore, the current study aims to investigate the moderating role of gender between tourist engagement and loyalty.

To address the objectives of this research, we apply partial least squares - structural equation modeling (PLS-SEM) to assess measurement model and structural model for male and female tourists, and compare these results using multigroup analysis (MGA). Moreover, we use fuzzyset qualitative comparative analysis (fsQCA) and necessity condition analysis (NCA) for both 
groups of male and female tourists to identify and compare sufficient and necessary configurations (i.e., recipes) to generate loyalty among male and female tourists.

\section{Literature Review}

\section{Tourist Engagement and Loyalty}

The concept of tourist engagement has been borrowed from broader concepts of consumer behavior and engagement (e.g., Bolton, 2011; Brodie et al., 2011; Patterson, Yu, \& de Ruyter, 2006; Vivek et al., 2012). Several studies in the consumer behavior literature have investigated consumer engagement from the perspective of relationship marketing theory these studies focus on the interactive experiences of consumers with other stakeholders and products (Brodie et al., 2013; Vivek et al., 2012). The concept of consumer engagement has also been explored from the organizational behavior perspective, in which links are made between consumer engagement and employment engagement, as well as various psychological factors, such as absorption, attention, and identification (Rothbard, 2001; So et al., 2014). Therefore, the consumer engagement concept includes emotional and cognitive domains, as well as interactive behaviors (Brodie et al., 2011, 2013; Hollebeek, 2011). Consequently, any attempt to elucidate a comprehensive understanding of tourist engagement should consider both these perspectives (Rasoolimanesh et al., 2019; So et al., 2014; So, King, Sparks, \& Wang, 2016). So et al. (2014), for example, considered both these psychological and interactive perspectives to examine tourism engagement, concluding that the concept was composed of five dimensions: enthusiasm, attention, absorption, interaction, and identification. Enthusiasm represents "an individual's strong level of excitement and interest regarding the focus of engagement, such as a brand" (So et al., 2014, p. 308). Therefore, based on this dimension of tourist engagement, an engaged tourist has enthusiastic feelings and passion about a specific destination. The attention dimension of tourist engagement denotes a level focused attention 
on a destination (Lin, Gregor, \& Ewing, 2008; Scholer \& Higgins, 2009). According to this dimension, an engaged tourist is interested in finding information and learning more about a destination (So et al., 2014). Going well beyond attention, the absorption dimension denotes the idea that a tourist is completely immersed in their experience of a destination or tourist site, such that the engaged tourist can easily lose track of how much time they spend at a destination (So et al., 2014). These three dimensions describe tourist engagement from a psychological perspective.

Nevertheless, tourist engagement might also be understood from an interactive perspective, which entails primarily interaction and identification dimensions. The interaction dimension is concerned with interactions between the tourist and other stakeholders, including local residents (Vivek, 2009). Tourists are thought to be highly engaged if they seek to participate in activities that bring them into contact with or that cause them to interact with local destination communities (So et al., 2014). The identification dimension, on the other hand, which is based on social identity theory, concerns the relationship between the tourist and their personal identity. In some cases, the tourist may identify so strongly with a site or a destination that it becomes inseparable from their sense of self; in such cases, criticism of their preferred destination wounds the tourist's ego as though it were the tourist themselves being criticized (Rasoolimanesh et al., 2019; So et al., 2014, 2016).

Previous studies have investigated the effects of tourist engagement on several factors, such as loyalty and satisfaction (Bryce et al., 2015; Leckie et al., 2016; So et al., 2016). These studies have demonstrated that highly engaged tourists also tend to be more loyal toward a destination and are thus more inclined to revisit (So et al., 2016). As indicated earlier, tourist engagement is both a psychological and interactive process, and these cognitive and emotional processes, as well as interactions with the destination, result in greater loyalty toward the 
destination and tourism site, thus encouraging the tourist to consider revisiting the destination (Bowden, 2009; Bryce et al., 2015).

\section{Gender Differences in Tourist Engagement and Loyalty}

Different gendered tourists may have different reasons for engaging with a destination, and might express differences in their preferences for certain activities offered by a destination. To this end, exploring the phenomenon of tourist engagement from a gendered perspective may help those involved in marketing a destination to better identify who their potential visitors are and what it is that they are looking to engage with (Khoo-Lattimore \& Prayag, 2018).

There is a paucity of gender-specific travel research literature, with the majority of travel research assuming that most tourists are male. To this end, Breathnach, Henry, Drea, and O'Flaherty (1994) attest that "no allowance is made for gender differences in social research... because of a gender bias which subsumes female behaviour into that of the dominant male patterns" (p. 57). Where tourism research does consider gender it tends to be in relation to highly focused segments of the industry such as sex tourism (Berdychevsky, Gibson, \& Poria, 2013), girlfriend getaways (Khoo-Lattimore \& Gibson, 2018; Khoo-Lattimore, Prayag, \& Disegna, 2019; Mirehie, Gibson, Khoo-Lattimore, \& Prayag, 2018), solo female travelers (Fendt, \& Wilson, 2012; Wilson \& Little, 2005, 2008 ), and Asian women travelers (Yang, Khoo-Lattimore, \& Arcodia, 2018a, 2018b ). Notwithstanding, the growth of a small body of literature dedicated to gender differences in leisure activities, travel patterns, as well as travel and experience preferences can be seen (Collins \& Tisdell, 2002; Meng \& Uysal, 2008; Mottiar \& Quinn, 2004; Pung, Yung, Khoo-Lattimore, \& Del Chiappa, 2019).

There is general consensus among scholars that motivation and engagement are the two essential components that determine one's choice of destination (Kim et al., 2017; Li \& Cai, 2012; So et al., 2014). Hollebeek (2011) argues that engagement is particularly important in 
relation to tourism products and services that are contingent upon a tourist's active participation or involvement with the product or service. Hollebeek (2011) goes on to suggest that engagement is a multidimensional concept inclusive of behavioral elements; additionally, Ballantyne, Frow, Varey, and Payne (2011) proposes that despite gender differences, tourist engagement can nonetheless be evaluated through experimental and reflective methods. To this end, Bem (1981) and Spence (1984) introduced two gender identity theories in order to explain the effects of gender on the consumption behavior of services or products. Both these theories emphasize the concept of gender-consumerism. Spence (1984) suggests that gender identity is predictive in relation to gender-related behaviors or patterns of engagement with a destination or tourism activity. Bem (1981), on the other hand, explains that an individual's engagement or choice of activities will be consistent with their gender identity. Several studies suggest that women tend to show a preference for engaging in leisure activities, dancing, visiting relatives, and shopping (Carr, 2001; Deem, 1986; Mieckzowski, 1990). The identification of such widespread gendered tourist preferences suggests that understanding gendered tourist engagement and loyalty might be becoming increasingly important (Omar, Abooali, Mohamed, \& Mohamad, 2014; Salazar, 2012).

Moreover, the evidence suggests that gendered tourist engagement and loyalty might be dependent upon the selection of activities and services offered by a tourism destination (Ryan, Henley, \& Soutar, 1998). Therefore, tourism operators must develop strategies aimed at targeting the specific wants and needs of their target market and match these with the desires of the gendered tourist ( Khoo-Lattimore \& Prayag, 2018; Ryan et al., 1998). The study by Kinnaird, Kothari, and Hall (1994) investigates the role of gender engagement in tourism, and concludes that the gender engagement may be related to socio-cultural norms and values associated with the places they live which reflects upon the activities they do during consumption or tourism services (Pawson \& Banks, 1993). This idea has the support of Ryan 
et al. (1998), arguing that "a self-catering camping holiday may be experienced differently by males for whom it represents a change, and by females for whom it may be a variation on a (too) familiar theme” (p. 2308). More importantly, Uysal, McGehee, and Loker-Murphy (1996) suggest that females are more likely motivated by culture, as well as opportunities to engage in family bonding and displays of social prestige; while males place more emphasis on sporting and adventure activities while enjoying the travel experience. Jönsson and Devonish (2008) also argue that traditional gender roles result in the perceived need to circumscribe one's interests; consequently, different gendered tourists might be expected to self-regulate their level of engagement with a tourism setting, choosing activities that match with their perceived gender norms. According to Jaffé (2006), women differ significantly from men in their shopping for tourism products and services. Female consumers tend to be more pragmatic and status-orientated as compared to men (Jaffé, 2006); moreover, women pay more attention to details, the purpose of the product or service, rely on the recommendations of others, and when satisfied, tend to become very loyal to a product or service supplied by specific vendor (Evanschitzky \& Wunderlich, 2006; Sabina \& Nicolae, 2013).

Therefore, the following five research hypotheses are articulated to describe the differences between male and female tourists for the effects of the engagement dimensions on loyalty:

H1: There is a significant difference for the effect of enthusiasm toward a destination on loyalty between female and male tourists.

H2: There is a significant difference for the effect of attention toward a destination on loyalty between female and male tourists.

H3: There is a significant difference for the effect of absorption toward a destination on loyalty between female and male tourists. 
H4: There is a significant difference for the effect of interaction toward a destination on loyalty between female and male tourists.

H5: There is a significant difference for the effect of identification toward a destination on loyalty between female and male tourists.

\section{Methodology}

\section{Data Collection Process}

This quantitative study relies upon a questionnaire for data collection. Question items used to measure the five dimensions of tourist engagement and loyalty have been adapted from So et al. (2014, 2016). A 5-point Likert scale was used with anchors ranging from 1 (strongly disagree) to 5 (strongly agree).

Kinabalu National Park (KNP) in Sabah, Malaysia, was inscribed as a world heritage site in 2000 by the United Nations Educational, Scientific, and Cultural Organization. KNP is the research setting from where data for this study was collected. Data was collected at the entrance to the park after tourists had completed their visit and had time to explore the park. KNP is a well-known tourism destination, both locally and internationally, and includes Mount Kinabalu, a wide diversity of flora and fauna, and the Poring Hot Spring. Non-probability purposive sampling was used for data collection. Researchers engaged participants in informal conversations about their experiences in the KNP, and whether they were interested in participating in this study. Those who expressed an interest in participating were subsequently asked to complete the questionnaire. We collected approximately 210 completed questionnaires in this study. G*Power was used to calculate the minimum sample size for power analysis (Faul, Erdfelder, Buchner, \& Lang, 2009). Power analysis identified a sample size of 92 for a statistical power of 0.80 . Therefore, with sample of 210 completed 
questionnaires, filled in by both male and female respondents, the sample was more than large enough to perform the analysis.

Of the 210 completed questionnaire, 91 questionnaires were completed by male tourists (43.3\%), and 119 by female tourists $(56.7 \%)$. Just over half of the respondents were single $(53.3 \%)$, while 98 respondents were married (46.7\%). Most of the respondents were local tourists (83.3\%), leaving only 35 respondents as international tourists (16.7\%). Most of the respondents were younger travelers $(n=157 ; 74.8 \%)$, with only 53 respondents being aged 35 years or older $(25.2 \%)$. Of the 210 respondents, $166(79 \%)$ were tertiary educated (e.g., undergraduate or postgraduate), while only 44 respondents (21\%) had a secondary level of education at most.

\section{Data Analysis}

PLS-SEM using SmartPLS 3.2.8 software (Ringle, Wende, \& Becker, 2015) was applied to assess both measurement and structural models, and to perform the MGA to compare the effects of each tourist engagement dimension on loyalty. PLS-SEM was employed because non-parametric SEM is more appropriate for MGA (Hair, Sarstedt, Ringle, \& Gudergan, 2017). Prior to the MGA, however, we needed to establish measurement invariance, for which we applied the measurement invariance for composite (MICOM) approach (Rasoolimanesh, Roldán, Jaafar, \& Ramayah, 2017). In addition, to ensure more robust insights, we performed fsQCA and NCA using fsQCA 3.0 software for both female and male tourists to understand and compare the sufficient and necessary conditions for female and male tourists to generate loyalty. 


\section{Results and Findings}

\section{Assessment of the Measurement Models}

Using PLS-SEM, we assessed the measurement and structural models for both female and male groups of tourists. The conceptual framework for this study included six reflective constructs, five of which are dimensions of tourist engagement (i.e., enthusiasm, attention, absorption, interaction, and identification), plus loyalty. To assess the measurement model, indicator and construct reliability, convergent validity, and the discriminant validity of these six reflective constructs for both female and male tourists were assessed (Ali, Rasoolimanesh, Sarstedt, Ringle, \& Ryu, 2018; Hair et al., 2017). The outer loading of the indicators for each construct should be higher than 0.7 to establish indicator reliability. To establish construct reliability and convergent validity, the Composite Reliability (CR) and rho A should be higher than 0.7, and the Average Variance Extracted (AVE) should be greater than 0.5 (Hair et al., 2017). Table 1 shows that the reliability and convergent validity for all six constructs involved in this study was acceptable for both female and male tourists. To assess discriminant validity, we relied on the most conservative approach, the heterotrait-monotrait (HTMT) ratio (Henseler, Ringle, \& Sarstedt, 2015). The HTMT ratio of each construct should be lower than 0.9 in order to establish discriminant validity (Henseler et al., 2015). Table 2 shows the results of $\mathrm{HTMT}_{0.90}$, indicating acceptable discriminant validity for both groups of female and male tourists.

[Table 1 about here]

[Table 2 about here]

The measurement invariance should be established for both groups of female and male tourists as a requirement to perform MGA (Rasoolimanesh et al., 2017; Sarstedt, Henseler, \& Ringle, 2011). Recent literature suggests that the MICOM approach is ideal for PLS-SEM 
(Henseler, Hubona, \& Ray, 2016; Md Noor, Rasoolimanesh, Jaafar, \& Barghi, 2019). The MICOM approach includes three steps: (a) assessment of configural invariance, (b) assessment of compositional invariance using the correlation between constructs, and (c) assessment of equal means and variances (Md Noor et al., 2019; Rasoolimanesh et al., 2017). Partial measurement invariance is required to perform MGA, which is obtained by establishing configural and compositional invariance. Table 3 shows the results of MICOM, thus indicating the establishment of partial measurement invariance. Therefore, based on the results of Table 3, MGA can be performed to compare the path coefficients for both groups and to test the hypotheses.

[Table 3 about here]

\section{Assessment of Structural Models and Multi-group Analysis}

Prior to performing the MGA to compare the effects of the five dimensions of tourist engagement on loyalty between female and male tourists and hypothesis testing, the structural model for the two groups must be assessed. To assess the structural model, the R-squared $\left(\mathrm{R}^{2}\right)$ and Stone-Geisser criterion $\left(\mathrm{Q}^{2}\right)$ for loyalty, as well as the significance of the path coefficients for the two groups should be assessed (Ali et al., 2018; Hair et al., 2017). The results produced $\mathrm{R}^{2}$ values of 0.562 for the loyalty of female tourists, and 0.611 for male tourists, both of which are considered high scores in the behavioral sciences (Rasoolimanesh et al., 2017). The value of $\mathrm{Q}^{2}$ should be greater than zero to demonstrate the predictive capability of a structural model (Ali et al., 2018); in this case, we found $\mathrm{Q}^{2}$ values of 0.409 and 0.414 for female and male tourists, respectively. These values are considered high, indicating that the model for both female and male groups possessed excellent predictive capabilities. Moreover, recent literature would suggest that it is important to determine the significance of the path coefficient using the bias-corrected (BCa) confidence intervals (Ali et al., 2018). Table 4 shows the positive and 
significant effects of enthusiasm, absorption, and identification on loyalty for female tourists; whereas for male tourists, only the effects of enthusiasm and attention on loyalty are significant.

[Table 4 about here]

Table 4 shows the results of MGA and hypothesis testing. Two conservative and nonparametric approaches-Henseler's MGA using bootstrapping and the permutation approach (Chin \& Dibbern, 2010; Henseler, Ringle, \& Sinkovics, 2009)—have been applied to compare the effects of tourist engagement dimensions on loyalty between male and female tourists. Using these two methods, the results of MGA show only a significant difference between the effect of attention on loyalty for female and male tourists. The effect of attention on loyalty is positive and strong for male tourists, whereas this effect is insignificant for female tourists. The effect of enthusiasm on loyalty is positive and strong for both groups, but the difference is not significant. Moreover, the effect of absorption on loyalty is significant for female and insignificant for male tourists, but the difference is not statistically significant.

\section{Results of fsQCA and NCA}

Given that the aforementioned results were not particularly insightful, we sought to gain deeper insights into the comparison between male and female tourists. As such, in addition to MGA, this study applied fsQCA and NCA to identify the sufficient and necessary conditions with which to generate loyalty among male and female tourists, and to compare these conditions across the two groups (Dul, 2016; Ragin, 2006, 2009). We chose to use fsQCA, a set-theoretical technique, which is usually thought of as a technique for the analysis of qualitative data and that works well with small sample. Nevertheless, fsQCA also can be 
considered a quantitative or variable-oriented technique, in which case it can be applied to the analysis of intermediate or larger samples (Berg-Schlosser, De Meur, Rihoux, \& Ragin, 2009). In fsQCA, using Boolean algebra, a series of sufficient combination of conditions (also called configurations, recipes, or causal models) are identified to predict or generate an outcome (Olya \& Gavilyan, 2017; Ragin, 2006). NCA, on the other hand, produces only a necessary single predictor or antecedent to generate an outcome (Dul, 2016). Therefore, two criteriaconsistency and coverage - are applied to identify the sufficient and necessary conditions to generate an outcome (Ragin, 2009). To this end, consistency and coverage should be higher than 0.8 and 0.2 , respectively, to identify the sufficient configurations or recipes for outcome in fsQCA; whereas, to identify the necessary condition in NCA to generate an outcome, both consistency and coverage should be greater than 0.9 (Dul, 2016; Ragin, 2009). This research has performed fsQCA and NCA using fsQCA 3.0 software; Tables 5 and 6 show the results of fsQCA and NCA, respectively, for female and male tourists. Table 5 shows that high loyalty among female tourists can be achieved in six configurations or combinations of tourist engagement dimensions. In Configuration 1, high levels of loyalty can be achieved if attention is high, and enthusiasm and identification are low. In Configuration 2, high levels of loyalty can be achieved if enthusiasm is high and identification and interaction are low. Configuration 3 shows that high levels of loyalty can be achieved with high levels of absorption, attention, and identification. Moreover, Configuration 4 shows that high levels of loyalty can be achieved with low levels of absorption, attention, and interaction, and high levels of identification. Configuration 5 shows that high levels of loyalty can be achieved for female tourists with only low levels of attention and enthusiasm, and high level of identification and interaction. The final configuration, Configuration 6, shows that high levels of attention, enthusiasm, identification, and interaction can generate high level of loyalty among female tourists. In the case of male tourists, however, there are only three sufficient configurations capable of 
achieving high levels of loyalty. Configuration 1: high levels of absorption and enthusiasm, and low levels of attention. Configuration 2: high levels of absorption, and low levels of enthusiasm and identification. And Configuration 3: high levels of absorption, enthusiasm, and interaction. Therefore, fsQCA reveals more complex configurations and combinations needed to achieve high levels of loyalty. The results for the fsQCA for male and female tourists shows different sufficient configurations for achieving high levels of loyalty among female and male tourists. Moreover, the results of NCA, shown in Table 6, indicate that absorption and enthusiasm are necessary predictors for achieving loyalty among male tourists, while no such necessary conditions exist in the case of female tourists for achieving loyalty.

\section{Discussion and conclusion}

This paper aims to compare the effects of enthusiasm, attention, absorption, interaction, and identification as the dimensions of tourist engagement on loyalty between male and female tourists. Previous literature has identified different patterns of behavior (Collins \& Tisdell, 2002), as well as motives and engagement levels between male and female travelers (Carr, 2001; Deem, 1986). Although some studies have suggested that gender engagement might be a function of the tourist's sociocultural norms and values (Pawson \& Banks, 1993), the current research demonstrates significant differences between the effects of engagement and loyalty between male and female tourists.

The results of PLS-SEM and MGA showed that the effects of attention on the loyalty of male tourists was significantly higher as compared to female tourists. This attention dimension of tourist engagement indicates that male tourists are highly focused and concentrating on their destination (Lin et al., 2008; Scholer \& Higgins, 2009). Therefore, the results show the importance of attaining and maintaining the attention of male tourists in order to generate loyalty within this gender group. Attention, however, was not found to have any 
significant effects on the loyalty of female tourists. This result was very surprising, particularly when we look at the level of attention among female tourists, which is significantly higher than level of attention achieved by male tourists (Table 3); nevertheless, the effect of this attention on the loyalty of male tourists is much stronger.

If we look at the results of the fsQCA, we can see high and low levels of attention in different sufficient configurations; moreover, these sufficient configurations reveal heterogeneity for the effect of attention on the loyalty of female tourists. This could be interpreted to mean that the effect of attention on the loyalty of female tourists differs according to their background, values, and culture (Pawson \& Banks, 1993). The results of PLS-SEM and MGA could not support any other significant differences between male and female tourists for the effects of enthusiasm, absorption, interaction, or identification. However, the fsQCA and NCA results provide us with additional insights with which to compare these effects between male and female tourists. The fsQCA results revealed three straightforward configurations capable of achieving high levels of loyalty among male tourists, with these results being confirmed by NCA. High level of enthusiasm and absorption with low levels of attention, or high levels of interaction and identification can generate high levels of loyalty among male tourists. However, the NCA results could not identify any necessary conditions for achieving loyalty among female tourists; moreover, the sufficient configurations for achieving loyalty among female tourists were very complex. Therefore, it would seem that high and low levels of all antecedents and dimensions of tourist engagement among identified configurations are required for achieving high levels of loyalty for female tourists. To this end, the results of fsQCA and NCA among female tourists show heterogeneity for the effects of enthusiasm, attention, absorption, interaction, and identification on loyalty, with this heterogeneity being less apparent among male tourists. In short, the results of this study demonstrate greater complexity and heterogeneity among female tourists based on various 
characteristics. This finding aligns with past studies which attribute this heterogeneity in women to other more complex gender-related factors such as self-image (Khoo-Lattimore \& Prayag, 2016). The results of this study highlight the importance of conducting gender-based research, in particular among female travelers in order to understand differences in the behavior, cognitions, and emotions, as well as the factors that influence their satisfaction and loyalty.

This research has significant practical implications for local authorities and correspondence organizations. The results of this study demonstrate various sufficient configurations and necessary conditions for achieving loyalty among tourists visiting KNP. Wishing to attract male tourists, local authorities should focus on instilling tourist enthusiasm and absorption, both of which are necessary conditions for achieving high levels of loyalty, as well as attention, which has the highest effect for achieving loyalty. Among female tourists, ensuring enthusiasm and absorption are important for achieving loyalty. Strategies to encourage absorption and engage female tourists may vary depending on their travel groups. For example, if a female is travelling with her family, then tourism providers need to be perceived to have taken care of everything so the female tourist can "forget everything else", "get carried away" and "be immersed" - research has shown that females travelling with families find it difficult to be engaged at a tourism site because gendered roles and social norms often mean that female travelers take responsibility for their travel companions and return from their holidays feeling like they need another holiday. Another example to increase absorption amongst female travelers is for destinations to increase safety for women, particularly solo women travelers. When one is conscious of the geography of fear and threat, one cannot be absorbed at the tourism site and therefore. Absorption could also be enhanced by creating some more inclusive, female-sensitive touch points, for example in the design of pre-booking, booking and consumption activities. A specific example could be making marketing materials 
more representative of the diversity of women in active engagement with tourism places (e.g. a middle-aged woman riding a wave), rather than positioning women as stereotypical and passive consumers (e.g. a young female in a bikini lying on a beach). For female tourists, the background, values, and culture of a destination play a more significant role in generating loyalty. Therefore, local authorities should look to capitalize upon the heterogeneity among female tourists to create a better sense of engagement and increase their loyalty toward a destination.

\section{Limitations and recommendations for future research}

As with all research projects, this study is not without limitations. For one, the items in the survey have raised more questions than they have answers. For example, in the dimension of enthusiasm, what would in turn influence passion for the tourism site, and if the generated excitement is internally or externally motivated? A qualitative investigation into the determinants of these dimensions would be worthwhile, not only for the advancement of theory but also for industry strategy planning. Second, we acknowledge the complexities in researching engagement and loyalty. We also recognise that gender itself is a complex topic, and made more complex when considering that tourism is a gendered space (Khoo-Lattimore \& Yang, 2018). Given the focus of the paper to examine gender differences for engagement and loyalty, we were not able to further explore the multiple dimensions surrounding each variable and the inter-relationships between them. For example, we have not distinguished the male and female participants and treated them as homogenous gender groups. This is because the aim of this research was to examine the level of engagement and loyalty between males and females rather than distinguishing the differences between male and female subgroups. Future research therefore could investigate the impact of each the five engagement dimensions on loyalty for different sub-segments of male and female tourists. 
On hindsight, we should have collected more demographic data - for example, including more international tourists, and establishing if the local tourists were from rural or urban areas. We have also not taken for example, self-image, culture and ethnicity of the local tourists into consideration and acknowledge that past research has shown that these cultural values and perception of image-congruence can influence the way tourists behave. We have however included four demographic variables (Age, education, marital status, and nationality) as control variables and tested statistically the effects of these control variables on model. None of these control variables showed significant effect on our model, indicating that these factors do not influence significantly in this study, but future researchers might want to empirically retest these. In addition, we have not considered the relationship between engagement, loyalty and how males and females use social media to access their tourism experiences so future scholars could establish these missing links. In the same vein, we have not explored how specific products and experiences might alter the levels of engagement and loyalty for males versus females, so this is another potential research agenda. Finally, future research could also study not just males and females but masculinities and femininities within the participants for a deeper understanding of gender differences when attempting to predict the influence of engagement on loyalty. 


\section{References}

Ali, F., Rasoolimanesh, S. M., Sarstedt, M., Ringle, C. M., \& Ryu, K. (2018). An assessment of the use of partial least squares structural equation modeling (PLS-SEM) in hospitality research. International Journal of Contemporary Hospitality Management, 30(1), 514-538. https://doi.org/10.1108/IJCHM-10-2016-0568

Ballantyne, D., Frow, P., Varey, R. J., \& Payne, A. (2011). Value propositions as communication practice: Taking a wider view. Industrial Marketing Management, 40(2), 202-210. https://doi.org/10.1016/j.indmarman.2010.06.032

Bem, S. L. (1981). Gender schema theory: A cognitive account of sex typing. Psychological Review, 88(4), 354-364.

Berdychevsky, L., Gibson, H., \& Poria, Y. (2013). Women's sexual behaviour in tourism: Loosening the bridle. Annals of Tourism Research, 42, 65-85.

Berg-Schlosser, D., De Meur, G., Rihoux, B., \& Ragin, C. (2009). Qualitative comparative analysis (QCA) as an approach. In B. Rihoux \& C. Ragin (Eds.), Configurational Comparative Methods: Qualitative Comparative Analysis (QCA) and Related Techniques (pp. 1-18). https://doi.org/10.4135/9781452226569

Bolton, R. N. (2011). Comment: Customer engagement: opportunities and challenges for organizations. Journal of Service Research, 14(3), 272-274. https://doi.org/10.1177/1094670511414582

Bowden, J. L.-H. (2009). The process of customer engagement: A conceptual framework. Journal of Marketing Theory and Practice, 17(1), 63-74. https://doi.org/10.2753/MTP1069-6679170105

Breathnach, P., Henry, M., Drea, S., \& O'Flaherty, M. (1994). Gender in Irish tourism employment. In V. Kinnaird \& D. R. Hall (Eds.), Tourism: A Gender Analysis. Chichester, England: Wiley. 
Brodie, R. J., Hollebeek, L. D., Jurić, B., \& Ilić, A. (2011). Customer engagement: Conceptual domain, fundamental propositions, and implications for research. Journal of Service Research, 14(3), 252-271. https://doi.org/10.1177/1094670511411703

Brodie, R. J., Ilic, A., Juric, B., \& Hollebeek, L. (2013). Consumer engagement in a virtual brand community: An exploratory analysis. Journal of Business Research, 66(1), 105114. https://doi.org/10.1016/j.jbusres.2011.07.029

Bryce, D., Curran, R., O’Gorman, K., \& Taheri, B. (2015). Visitors' engagement and authenticity: Japanese heritage consumption. Tourism Management, 46, 571-581. https://doi.org/10.1016/j.tourman.2014.08.012

Carr, N. (2001). An exploratory study of gendered differences in young tourists perception of danger within London. Tourism Management, 22(5), 565-570. https://doi.org/10.1016/S0261-5177(01)00014-0

Chin, W. W., \& Dibbern, J. (2010). An introduction to a permutation based procedure for multigroup PLS analysis: Results of tests of differences on simulated data and a cross cultural analysis of the sourcing of information system services between Germany and the USA. In V. Esposito Vinzi, W. W. Chin, J. Henseler, \& H. Wang (Eds.), Handbook of Partial Least Squares (pp. 171-193). https://doi.org/10.1007/978-3-540-32827-8_8

Collins, D., \& Tisdell, C. (2002). Gender and differences in travel life cycles. Journal of Travel Research, 41(2), 133-143. https://doi.org/10.1177/004728702237413

Deem, R. (1986). All work and no play? A study of women and leisure. Milton Keynes, England: Open University Press.

Dul, J. (2016). Identifying single necessary conditions with NCA and fsQCA. Journal of Business Research, 69(4), 1516-1523. https://doi.org/10.1016/j.jbusres.2015.10.134 
Evanschitzky, H., \& Wunderlich, M. (2006). An examination of moderator effects in the fourstage loyalty model. Journal of Service Research, 8(4), 330-345. https://doi.org/10.1177/1094670506286325

Faul, F., Erdfelder, E., Buchner, A., \& Lang, A.-G. (2009). Statistical power analyses using G*Power 3.1: Tests for correlation and regression analyses. Behavior Research Methods, 41(4), 1149-1160. https://doi.org/10.3758/BRM.41.4.1149

Fendt, L. S., \& Wilson, E. (2012). 'I just push through the barriers because I live for surfing': how women negotiate their constraints to surf tourism. Annals of Leisure Research, 15(1), 4-18.

Hair, J. F., Sarstedt, M., Ringle, C. M., \& Gudergan, S. (2017). Advanced issues in partial least squares structural equation modeling. Retrieved from https://nls.ldls.org.uk/welcome.html?ark:/81055/vdc_100044101027.0x000001

Henseler, J., Hubona, G., \& Ray, P. A. (2016). Using PLS path modeling in new technology research: Updated guidelines. Industrial Management \& Data Systems, 116(1), 2-20. https://doi.org/10.1108/IMDS-09-2015-0382

Henseler, J., Ringle, C. M., \& Sarstedt, M. (2015). A new criterion for assessing discriminant validity in variance-based structural equation modeling. Journal of the Academy of Marketing Science, 43(1), 115-135. https://doi.org/10.1007/s11747-014-0403-8

Henseler, J., Ringle, C. M., \& Sinkovics, R. R. (2009). The use of partial least squares path modeling in international marketing. In R. R. Sinkovics \& P. N. Ghauri (Eds.), Advances in International Marketing (Vol. 20, pp. 277-319). https://doi.org/10.1108/S1474-7979(2009)0000020014

Hollebeek, L. (2011). Exploring customer brand engagement: Definition and themes. Journal of Strategic $\quad$ Marketing, $\quad$ 19(7), 555-573. https://doi.org/10.1080/0965254x.2011.599493 
Jaffé, D. (2006). Reise-entscheidungen: Die Rolle von Frauen bei Kaufentscheidungen im Tourismus. Blue stone gender marketing [Travel-decisions: The role of women in purchasing decisions in tourism]. Berlin, Germany: Blue Stone Gender Marketing. Jönsson, C., \& Devonish, D. (2008). Does nationality, gender, and age affect travel motivation? A case of visitors to the Caribbean island of Barbados. Journal of Travel \& Tourism Marketing, 25(3-4), 398-408. https://doi.org/10.1080/10548400802508499

Kim, E., Chiang, L., \& Tang, L. (2017). Investigating wellness tourists' motivation, engagement, and loyalty: In search of the missing link. Journal of Travel \& Tourism Marketing, 34(7), 867-879. https://doi.org/10.1080/10548408.2016.1261756

Kinnaird, V., Kothari, U., \& Hall, D. R. (1994). Tourism: Gender perspectives. In V. Kinnaird \& D. R. Hall (Eds.), Tourism: A Gender Analysis (pp. 1-34). Chichester, England: Wiley.

Khoo-Lattimore, C., \& Prayag, G. (2016). Accommodation preferences of the girlfriend getaway market in Malaysia. International Journal of Contemporary Hospitality Management, 28 (12), 2748-2770.

Khoo-Lattimore, C., \& Prayag, G. (2018). Understanding Asian and Western women on girlfriend getaways: The relationship between motivation and accommodation performance. Journal of Hospitality Marketing \& Management, 27(2), 239-259.

Khoo-Lattimore, C., \& Gibson, H. J. (2018). Understanding women's accommodation experiences on girlfriend getaways: a pragmatic action research approach. Current Issues in Tourism, 21(2), 191-209.

Khoo-Lattimore, C., Prayag, G., \& Disegna, M. (2019). Me, My girls, and the ideal hotel: segmenting motivations of the girlfriend getaway market using fuzzy C-Medoids for fuzzy data. Journal of Travel Research, 58(5), 774-792. 
Khoo-Lattimore, C., \& Yang, E. (2018). Tourism gender studies. In C. Cooper, S. Volo, W. C. Gartner, \& N. Scott (Eds.), The SAGE handbook of tourism management: Applications of theories and concepts to tourism (Vol. 2, pp. 38-48). London: SAGE.

Leckie, C., Nyadzayo, M. W., \& Johnson, L. W. (2016). Antecedents of consumer brand engagement and brand loyalty. Journal of Marketing Management, 32(5-6), 558-578. https://doi.org/10.1080/0267257X.2015.1131735

Li, M., \& Cai, L. A. (2012). The Effects of Personal Values on Travel Motivation and Behavioral Intention. Journal of Travel Research, 51(4), 473-487. https://doi.org/10.1177/0047287511418366

Lin, A., Gregor, S., \& Ewing, M. (2008). Developing a scale to measure the enjoyment of Web experiences. Journal of Interactive Marketing, 22(4), 40-57. https://doi.org/10.1002/dir.20120

Md Noor, S., Rasoolimanesh, S. M., Jaafar, M., \& Barghi, R. (2019). Inscription of a destination as a world heritage site and residents' perceptions. Asia Pacific Journal of Tourism Research, 24(1), 14-30. https://doi.org/10.1080/10941665.2018.1541183

Meng, F., \& Uysal, M. (2008). Effects of gender differences on perceptions of destination attributes, motivations, and travel values: An examination of a nature-based resort destination. Journal of Sustainable Tourism, 16(4), 445-466. https://doi.org/10.1080/09669580802154231

Mieckzowski, Z. (1990). World Trends in Tourism and Recreation. New York, NY: Peter Lang.

Mirehie, M., Gibson, H. J., Khoo-Lattimore, C., \& Prayag, G. (2018). An exploratory study of hospitality needs and preferences of US Girlfriend Getaways. Journal of Hospitality Marketing \& Management, 27(7), 811-832. 
Mottiar, Z., \& Quinn, D. (2004). Couple dynamics in household tourism decision making: Women as the gatekeepers? Journal of Vacation Marketing, 10(2), 149-160. https://doi.org/10.1177/135676670401000205

Olya, H. G. T., \& Gavilyan, Y. (2017). Configurational models to predict residents' support for tourism development. Journal of Travel Research, 56(7), 893-912. https://doi.org/10.1177/0047287516667850

Omar, S. I., Abooali, G., Mohamed, B., \& Mohamad, D. (2014). Gender differences in perceived importance and performance of Penang Island attributes. SHS Web of Conferences, 12, 01065. https://doi.org/10.1051/shsconf/20141201065

Patterson, P., Yu, T., \& de Ruyter, K. (2006). Understanding customer engagement in services. Advancing Theory, Maintaining Relevance: Proceedings of ANZMAC 2006 Conference, 4-6. Brisbane, Queensland: Australia and New Zealand Marketing Academy Conference.

Pawson, E., \& Banks, G. (1993). Rape and fear in a New Zealand city. Area, 25(1), 55-63.

Pritchard, A., \& Morgan, N. J. (2000). Privileging the male gaze. Annals of Tourism Research, 27(4), 884-905. https://doi.org/10.1016/S0160-7383(99)00113-9

Pung, J. M., Yung, R., Khoo-Lattimore, C., \& Del Chiappa, G. (2019). Transformative travel experiences and gender: a double duoethnography approach. Current Issues in Tourism, 1-21.

Ragin, C. C. (2006). Set relations in social research: Evaluating their consistency and coverage. Political Analysis, 14(3), 291-310. https://doi.org/10.1093/pan/mpj019

Ragin, C. C. (2009). Redesigning Social Inquiry: Fuzzy Sets and Beyond. Chicago, IL: University of Chicago Press. 
Rasoolimanesh, S. M., Md Noor, S., Schuberth, F., \& Jaafar, M. (2019). Investigating the effects of tourist engagement on satisfaction and loyalty. The Service Industries Journal, 39(7-8), 559-574. https://doi.org/10.1080/02642069.2019.1570152

Rasoolimanesh, S. M., Roldán, J. L., Jaafar, M., \& Ramayah, T. (2017). Factors influencing residents' perceptions toward tourism development: Differences across rural and urban world heritage sites. Journal of Travel Research, 56(6), 760-775. https://doi.org/10.1177/0047287516662354

Ringle, C., Wende, S., \& Becker, J. (2015). SmartPLS 3 (Version 3.2.7). Boenningstedt, Germany: SmartPLS GmbH.

Rothbard, N. P. (2001). Enriching or depleting? The dynamics of engagement in work and family roles. Administrative Science Quarterly, 46(4), 655. https://doi.org/10.2307/3094827

Ryan, M., Henley, N., \& Soutar, G. (1998). Gender differences in tourism destination: Implications for tourism marketers. Presented at the Australian and New Zealand Marketing Conference, Dunedin, New Zealand.

Sabina, J. M., \& Nicolae, J. C. (2013). Gender trends in tourism destination. Procedia - Social and Behavioral Sciences, 92, 437-444. https://doi.org/10.1016/j.sbspro.2013.08.698

Salazar, N. B. (2012). Tourism and cosmopolitanism: A view from below. International Journal of Tourism Anthropology, 1(1), 55-69.

Sarstedt, M., Henseler, J., \& Ringle, C. M. (2011). Multigroup analysis in partial least squares (PLS) path modeling: Alternative methods and empirical results. In M. Sarstedt, M. Schwaiger, \& C. R. Taylor (Eds.), Advances in International Marketing (Vol. 22, pp. 195-218). https://doi.org/10.1108/S1474-7979(2011)0000022012 
Scholer, A. A., \& Higgins, E. T. (2009). Exploring the complexities of value creation: The role of engagement strength. Journal of Consumer Psychology, 19(2), 137-143. https://doi.org/10.1016/j.jcps.2009.02.007

So, K. K. F., King, C., \& Sparks, B. (2014). Customer engagement with tourism brands: Scale development and validation. Journal of Hospitality \& Tourism Research, 38(3), 304329. https://doi.org/10.1177/1096348012451456

So, K. K. F., King, C., Sparks, B. A., \& Wang, Y. (2016). The role of customer engagement in building consumer loyalty to tourism brands. Journal of Travel Research, 55(1), 6478. https://doi.org/10.1177/0047287514541008

Spence, J. T. (1984). Masculinity, femininity, and gender-related traits: A conceptual analysis and critique of current research. In B. A. Maher \& W. B. Maher (Eds.), Progress in Experimental Personality Research (Vol. 13, pp. 1-97). https://doi.org/10.1016/B978$0-12-541413-5.50006-1$

Uysal, M., McGehee, N. G., \& Loker-Murphy, L. (1996). The Australian international pleasure travel market: Motivations from a gendered perspective. Journal of Tourism Studies, $7(1), 45-57$.

Vivek, S. D. (2009). A scale of consumer engagement (Doctoral dissertation). University of Alabama, Tuscaloosa, AL.

Vivek, S. D., Beatty, S. E., \& Morgan, R. M. (2012). Customer engagement: Exploring customer relationships beyond purchase. The Journal of Marketing Theory and Practice, 20(2), 122-146. https://doi.org/10.2753/MTP1069-6679200201

Wilson, E., \& Little, D. E. (2008). The solo female travel experience: Exploring the 'geography of women's fear'. Current Issues in Tourism, 11(2), 167-186.

Wilson, E., \& Little, D. E. (2005). A "relative escape"? The impact of constraints on women who travel solo. Tourism Review International, 9(2), 155-175. 
Yang, E. C. L., Khoo-Lattimore, C., \& Arcodia, C. (2018a). Power and empowerment: How Asian solo female travellers perceive and negotiate risks. Tourism Management, 68, $32-45$.

Yang, E. C. L., Khoo-Lattimore, C., \& Arcodia, C. (2018b). Constructing space and self through risk taking: A case of Asian solo female travelers. Journal of Travel Research, 57(2), 260-272.

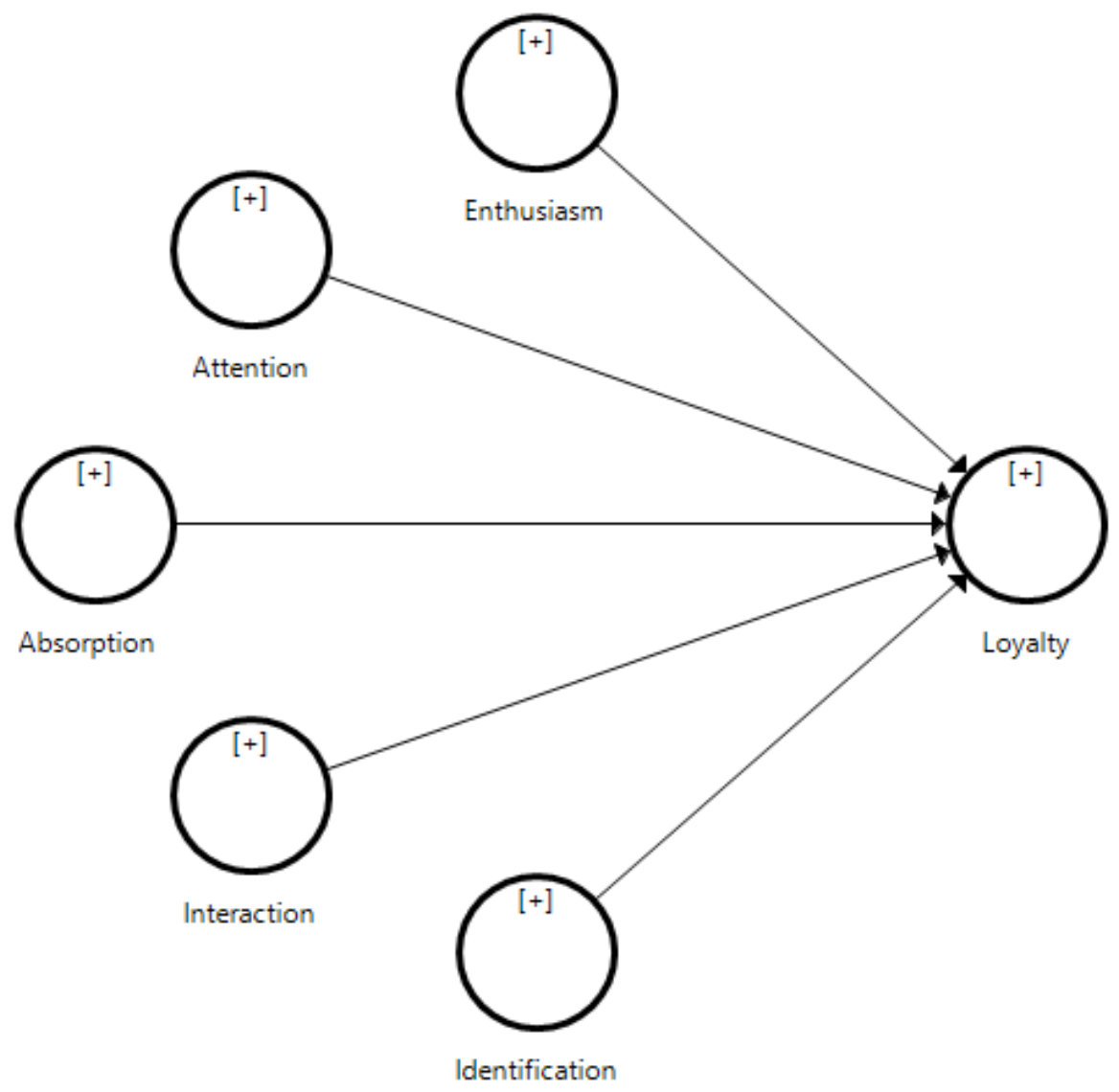

Figure 1. Conceptual framework. 
Table 1.

Results of the Assessment of Measurement Model

\begin{tabular}{|c|c|c|c|c|c|c|}
\hline \multirow{2}{*}{$\begin{array}{c}\text { Construct / } \\
\text { Associated Items }\end{array}$} & \multicolumn{2}{|c|}{ Loading } & \multicolumn{2}{|c|}{ rho A - CR } & \multicolumn{2}{|c|}{ AVE } \\
\hline & Female & Male & Female & Male & Female & Male \\
\hline Enthusiasm & & & $0.911-0.936$ & $0.949-0.962$ & 0.785 & 0.863 \\
\hline EN1 & 0.868 & 0.901 & & & & \\
\hline EN2 & 0.932 & 0.950 & & & & \\
\hline EN3 & 0.911 & 0.971 & & & & \\
\hline EN4 & 0.829 & 0.893 & & & & \\
\hline Attention & & & $0.906-0.934$ & $0.851-0.896$ & 0.779 & 0.684 \\
\hline AT1 & 0.848 & 0.767 & & & & \\
\hline AT2 & 0.888 & 0.857 & & & & \\
\hline AT3 & 0.910 & 0.843 & & & & \\
\hline AT4 & 0.883 & 0.839 & & & & \\
\hline Absorption & & & $0.908-0.927$ & $0.921-0.934$ & 0.719 & 0.741 \\
\hline AB1 & 0.786 & 0.782 & & & & \\
\hline AB2 & 0.852 & 0.878 & & & & \\
\hline AB3 & 0.862 & 0.864 & & & & \\
\hline AB4 & 0.892 & 0.885 & & & & \\
\hline AB5 & 0.844 & 0.891 & & & & \\
\hline Interaction & & & $0.905-0.926$ & $0.922-0.933$ & 0.715 & 0.736 \\
\hline IN1 & 0.806 & 0.830 & & & & \\
\hline IN2 & 0.826 & 0.929 & & & & \\
\hline IN3 & 0.864 & 0.890 & & & & \\
\hline IN4 & 0.866 & 0.836 & & & & \\
\hline IN5 & 0.864 & 0.795 & & & & \\
\hline Identification & & & $0.874-0.921$ & $0.881-0.919$ & 0.797 & 0.791 \\
\hline ID1 & 0.859 & 0.859 & & & & \\
\hline ID2 & 0.906 & 0.899 & & & & \\
\hline ID3 & 0.911 & 0.910 & & & & \\
\hline Loyalty & & & $0.929-0.945$ & $0.911-0.933$ & 0.775 & 0.736 \\
\hline LOY1 & 0.865 & 0.836 & & & & \\
\hline LOY2 & 0.858 & 0.897 & & & & \\
\hline LOY3 & 0.895 & 0.866 & & & & \\
\hline LOY4 & 0.903 & 0.853 & & & & \\
\hline LOY5 & 0.881 & 0.837 & & & & \\
\hline
\end{tabular}

Note: See Appendix 1 for full name of items 
Table 2.

Discriminant Validity Assessment (HTMT 0.9 ration)

\begin{tabular}{|c|c|c|c|c|c|c|c|c|c|c|c|c|}
\hline & \multicolumn{6}{|c|}{ Female } & \multicolumn{6}{|c|}{ Male } \\
\hline & Enthusiasm & Attention & Absorption & Interaction & Identification & Loyalty & Enthusiasm & Attention & Absorption & Interaction & Identification & Loyalty \\
\hline \multicolumn{13}{|l|}{ Enthusiasm } \\
\hline Attention & 0.718 & & & & & & 0.833 & & & & & \\
\hline Absorption & 0.681 & 0.818 & & & & & 0.835 & 0.897 & & & & \\
\hline Interaction & 0.699 & 0.711 & 0.874 & & & & 0.784 & 0.854 & 0.843 & & & \\
\hline Identification & 0.716 & 0.631 & 0.594 & 0.753 & & & 0.832 & 0.807 & 0.626 & 0.761 & & \\
\hline Loyalty & 0.773 & 0.588 & 0.644 & 0.636 & 0.643 & & 0.769 & 0.807 & 0.684 & 0.687 & 0.750 & \\
\hline
\end{tabular}

Table 3.

Results of Invariance Measurement Testing Using Permutation

\begin{tabular}{|c|c|c|c|c|c|c|c|c|c|c|c|}
\hline \multirow[t]{2}{*}{ Constructs } & \multirow[t]{2}{*}{$\begin{array}{l}\text { Configural } \\
\text { invariance }\end{array}$} & \multicolumn{2}{|c|}{$\begin{array}{l}\text { Compositional invariance } \\
(\text { Correlation }=1)\end{array}$} & \multirow{2}{*}{$\begin{array}{l}\text { Partial } \\
\text { measurement } \\
\text { invariance } \\
\text { established }\end{array}$} & \multicolumn{2}{|c|}{ Equal mean assessment } & \multirow[b]{2}{*}{ Equal } & \multicolumn{2}{|c|}{ Equal variance assessment } & \multirow[b]{2}{*}{ Equal } & \multirow{2}{*}{$\begin{array}{l}\text { Full } \\
\text { measurement } \\
\text { invariance } \\
\text { established }\end{array}$} \\
\hline & & $\mathrm{C}=1$ & $\begin{array}{l}\text { Confidence } \\
\text { Interval (CIs) }\end{array}$ & & $\begin{array}{l}\text { Differences } \\
\text { (Female - } \\
\text { Male) }\end{array}$ & $\begin{array}{l}\text { Confidence } \\
\text { Interval (CIs) }\end{array}$ & & Differences & $\begin{array}{l}\text { Confidence } \\
\text { Interval (CIs) }\end{array}$ & & \\
\hline Enthusiasm & Yes & 1.000 & {$[0.999,1.000]$} & Yes & 0.120 & {$[-0.269,0.273]$} & Yes & -0.117 & {$[-0.282,0.285]$} & Yes & Yes \\
\hline Attention & Yes & 0.999 & {$[0.997,1.000]$} & Yes & 0.303 & {$[-0.281,0.267]$} & No & 0.022 & {$[-0.341,0.345]$} & Yes & No \\
\hline Absorption & Yes & 1.000 & {$[0.998,1.000]$} & Yes & 0.172 & {$[-0.270,0.278]$} & Yes & -0.111 & {$[-0.303,0.320]$} & Yes & Yes \\
\hline Interaction & Yes & 0.999 & {$[0.992,1.000]$} & Yes & 0.106 & {$[-0.266,0.278]$} & Yes & -0.103 & {$[-0.353,0.366]$} & Yes & Yes \\
\hline Identification & Yes & 0.998 & {$[0.998,1.000]$} & Yes & -0.018 & {$[-0.272,0.268]$} & Yes & 0.040 & {$[-0.315,0.346]$} & Yes & Yes \\
\hline Loyalty & Yes & 1.000 & {$[0.999,1.000]$} & Yes & 0.163 & {$[-0.277,0.268]$} & Yes & -0.056 & {$[-0.294,0.308]$} & No & Yes \\
\hline
\end{tabular}


Table 4.

Results of Hypothesis Testing

\begin{tabular}{|c|c|c|c|c|c|c|c|c|c|}
\hline \multirow[b]{2}{*}{ Hypothesis } & \multirow[b]{2}{*}{ Relationships } & \multicolumn{2}{|c|}{ Path Coefficient } & \multicolumn{2}{|c|}{$\begin{array}{c}\text { Confidence Interval (95\%) } \\
\text { Bias Corrected }\end{array}$} & \multirow{2}{*}{$\begin{array}{c}\text { Path } \\
\text { Coefficient } \\
\text { Difference }\end{array}$} & \multicolumn{2}{|c|}{$P$-value Difference } & \multirow[b]{2}{*}{ Supported } \\
\hline & & Female & Male & Female & Male & & $\begin{array}{l}\text { Henseler's } \\
\text { MGA }\end{array}$ & $\begin{array}{l}\text { Permutation } \\
\text { test }\end{array}$ & \\
\hline $\mathrm{H} 1$ & Enthusiasm $\rightarrow$ Loyalty & 0.482 & 0.294 & {$[0.330,0.656]$} & {$[-0.019,0.541]$} & 0.188 & 0.164 & 0.284 & $\mathrm{No} / \mathrm{No}$ \\
\hline $\mathrm{H} 2$ & Attention $\rightarrow$ Loyalty & -0.045 & 0.375 & {$[-0.253,0.141]$} & {$[0.047,0.631]$} & -0.420 & $0.976^{*}$ & $0.028 *$ & Yes/Yes \\
\hline $\mathrm{H} 3$ & Absorption $\rightarrow$ Loyalty & 0.228 & -0.020 & {$[0.028,0.433]$} & {$[-0.340,0.260]$} & 0.248 & 0.128 & 0.217 & $\mathrm{No} / \mathrm{No}$ \\
\hline $\mathrm{H} 4$ & Interaction $\rightarrow$ Loyalty & 0.020 & 0.024 & {$[-0.143,0.211]$} & {$[-0.166,0.222]$} & -0.004 & 0.518 & 0.981 & No/No \\
\hline H5 & Identification $\rightarrow$ Loyalty & 0.164 & 0.186 & {$[0.026,0.326]$} & {$[-0.014,0.385]$} & -0.022 & 0.561 & 0.886 & $\mathrm{No} / \mathrm{No}$ \\
\hline
\end{tabular}

Note: In Henseler's MGA approch, a p value lower than 0.05 or greater than 0.95 shows $5 \%$ level significant differences across two groups. 
Table 5.

Sufficient Configurations for Loyalty

\begin{tabular}{|c|c|c|c|}
\hline Configurations & $\begin{array}{l}\text { Raw } \\
\text { coverage }\end{array}$ & $\begin{array}{l}\text { Unique } \\
\text { coverage }\end{array}$ & Consistency \\
\hline \multicolumn{4}{|l|}{ Configurations for loyalty (Female tourists) } \\
\hline \multicolumn{4}{|c|}{ Loyalty $=f$ (absorption, attention, enthusiasm, identification, interaction) } \\
\hline Conf 1: attention* ${ }^{*}$ enthusiasm* $\sim$ identification & 0.545 & 0.012 & 0.903 \\
\hline Conf 2: enthusiasm* ${ }^{*}$ identification* $*$ interaction & 0.556 & 0.015 & 0.910 \\
\hline Conf 3: absorption*attention*identification & 0.766 & 0.025 & 0.946 \\
\hline Conf 4: absorption* a attention*identification* interaction & 0.524 & 0.016 & 0.889 \\
\hline Con 5: attention* ${ }^{*}$ enthusiasm*identification*interaction & 0.519 & 0.006 & 0.921 \\
\hline Conf 6: attention*enthusiasm*identification*interaction & 0.726 & 0.010 & 0.957 \\
\hline \multicolumn{4}{|l|}{ solution coverage: 0.883} \\
\hline \multicolumn{4}{|l|}{ solution consistency: 0.860} \\
\hline \multicolumn{4}{|l|}{ Configurations for loyalty (Male tourists) } \\
\hline \multicolumn{4}{|c|}{ Loyalty $=f$ (absorption, attention, enthusiasm, identification, interaction) } \\
\hline Conf 1: absorption* attention*enthusiasm & 0.674 & 0.115 & 0.992 \\
\hline Conf 2: absorption*enthusiasm*identification & 0.746 & 0.036 & 0.995 \\
\hline Conf 3: absorption*enthusiasm*interaction & 0.758 & 0.030 & 0.995 \\
\hline solution coverage: 0.939 & & & \\
\hline solution consistency: 0.989 & & & \\
\hline
\end{tabular}


Table 6.

Results of NCA for Loyalty

\begin{tabular}{|c|c|c|}
\hline Antecedents & Consistency & Coverage \\
\hline \multicolumn{3}{|c|}{ Outcome = Loyalty $/$ Female tourists } \\
\hline absorption & 0.864 & 0.867 \\
\hline absorption & 0.663 & 0.683 \\
\hline attention & 0.876 & 0.870 \\
\hline attention & 0.662 & 0.690 \\
\hline enthusiasm & 0.868 & 0.873 \\
\hline enthusiasm & 0.655 & 0.674 \\
\hline identification & 0.858 & 0.858 \\
\hline identification & 0.675 & 0.698 \\
\hline interaction & 0.855 & 0.859 \\
\hline interaction & 0.674 & 0.694 \\
\hline \multicolumn{3}{|c|}{ Outcome = Loyalty $/$ Male tourists } \\
\hline absorption & 0.965 & 0.970 \\
\hline absorption & 0.608 & 1.000 \\
\hline attention & 0.771 & 0.954 \\
\hline attention & 0.692 & 0.871 \\
\hline enthusiasm & 0.969 & 0.974 \\
\hline enthusiasm & 0.609 & 1.000 \\
\hline identification & 0.767 & 0.952 \\
\hline ridentification & 0.687 & 0.861 \\
\hline interaction & 0.763 & 0.946 \\
\hline interaction & 0.701 & 0.879 \\
\hline
\end{tabular}


Appendix 1 . The adapted items to measure tourist engagement, and loyalty.

Questions

\begin{tabular}{|c|c|}
\hline & Enthusiasm \\
\hline EN1 & I am heavily into this tourism site. \\
\hline EN2 & I am passionate about this tourism site. \\
\hline EN3 & I am enthusiastic about this tourism site. \\
\hline \multirow{2}{*}{ EN4 } & I feel excited about this tourism site. \\
\hline & Attention \\
\hline AT1 & I like to learn more about this tourism site. \\
\hline AT2 & Anything related to this tourism site grabs my attention. \\
\hline AT3 & I concentrate a lot on my visit at this tourism site. \\
\hline \multirow[t]{2}{*}{ AT4 } & I like learning more about this tourism site. \\
\hline & Absorption \\
\hline AB1 & When I am interacting with the tourism site, I forget everything else around me. \\
\hline AB2 & When I am interacting with the tourism site, I get carried away. \\
\hline AB3 & When interacting with the tourism site, it is difficult to detach myself. \\
\hline $\mathrm{AB} 4$ & In my interaction with the tourism site, I am immersed. \\
\hline \multirow[t]{2}{*}{ AB5 } & When interacting with the tourism site intensely, I feel happy. \\
\hline & Interaction \\
\hline IN1 & In general, I like to get involved in the tourism site community discussions. \\
\hline IN2 & I am someone who enjoys interacting with like-minded community in the tourism \\
\hline IN3 & I am someone who likes to actively participate in the tourism site community discussions. \\
\hline IN4 & $\begin{array}{l}\text { In general, I thoroughly enjoy exchanging ideas with other people in the tourism site } \\
\text { community. }\end{array}$ \\
\hline \multirow[t]{2}{*}{ IN5 } & I often participate in activities of the tourism site community. \\
\hline & Identification \\
\hline ID1 & When someone criticizes this tourism site, it feels like a personal insult \\
\hline ID2 & $\begin{array}{l}\text { When I talk about this tourism site, I usually say 'we' rather than 'they' because the } \\
\text { identity of the site suites me. }\end{array}$ \\
\hline \multirow[t]{2}{*}{ ID3 } & When someone praises this tourism site, it feels like a personal compliment. \\
\hline & Loyalty \\
\hline LOY1 & I would say positive things about this tourism site to other people. \\
\hline LOY2 & I would recommend this tourism site to someone who seeks my advice. \\
\hline LOY3 & I would encourage friends and relatives to do business with this tourism site. \\
\hline LOY4 & I would do more visits with this tourism site in the next few years. \\
\hline LOY5 & I am willing to visit this tourism site again in the future \\
\hline
\end{tabular}

